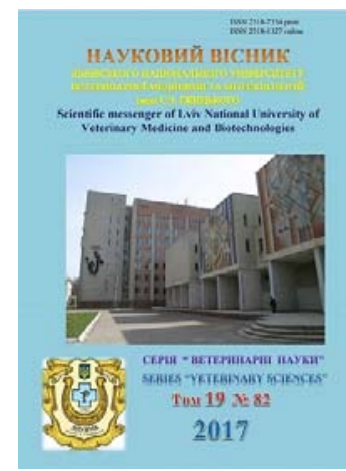

Науковий вісник Львівського національного університету ветеринарної медицини та біотехнологій імені С.З. Гжицького

Scientific Messenger of Lviv National University of Veterinary Medicine and Biotechnologies

doi:10.15421/nvlvet8210

ISSN 2518-7554 print

ISSN 2518-1327 online

http://nvlvet.com.ua/

УДК 619.9:636.7

\title{
Патоморфологічна характеристика парвовірусного ентериту в собак
}

\author{
М.Л. Радзиховський, С.С. Заїка \\ nickvet@ukr.net, lana_zaika@ukr.net \\ Житомирський національний агроекологічний університет, \\ вул. Корольова, 39, Житомир, 10002, Украӥна
}

Вірусні ентерити займають провідне місце в інфекиійній патології собак і призводять до тяжких розладів таких систем, як илунково-кишкової, серцево-судинної та дихальної. Комплексна діагностика иісї патології у собак розроблена недостатньо. Висока варіабельність клінічних ознак за парвовірусного ентериту, складність апеляції великим числом якісних показників ускладнюють постановку діагнозу на це захворювання для практичного ветеринарного лікаря. Методи патоморфологічної діагностики є простими, дешевими та доступними будь-якому лікарю ветеринарної медицини. Саме $з$ них починається встановлення причини загибелі тварини при багатьох хворобах і патологічних станах изі методи залишаються вирішальними при постановці діагнозу.

Роботу виконували на факультеті ветеринарної медицини Житомирського національного агроекологічного університету, а також у ветеринарних клініках міста Житомира в період з 2014 по 2017 рік на породних і безпородних собаках.

Діагностичні дослідження на підтвердження парвовірусного ентериту проводили за допомогою експрес тестів VetExpert та в ІФА і ПЛР.

У статті наведено результати вивчення патологоанатомічних змін в собак за парвовірусного ентериту, які залежали від форми прояву хвороби - кишкової, серчевої або змішаної. Найбільш виражені патолого-анатомічні зміни знаходили у шлунково-кишковому тракті (при кишковій формі), головним чином у тонкому відділі кишечнику. При кардіальній формі парвовірусного ентериту основні зміни спостерігали в сериі. Характерним для даної форми хвороби є міокардит альтеративного типу.

У загиблих тварин виявлено комплекс патологоанатомічних ознак, які можна вважати характерними для парвовірусного ентериту: геморагічний ентерит, серозно-геморагічне запалення брижових лімфовузлів, ознаки гепатиту, гострий альтеративний міокардит, в легенях - крововиливи та вогнища ателектазів та збільшення селезінки.

Ключові слова: собаки, парвовірусний ентерит, патологоанатомічний розтин, макроскопічні зміни, патоморфологічна діагностика, міокардит, крововиливи.

\section{Патоморфологическая характеристика парвовирусного энтерита у собак}

\author{
Н.Л. Радзиховский, С.С. Заика \\ nickvet@ukr.net, lana_zaika@ukr.net \\ Житомирский наиоональный агроекологический университет, \\ ул. Королёва, 39, Житомир, 10002, Украина
}

\begin{abstract}
Вирусные энтериты занимают ведущее место в инфекиионной патологии собак и приводят к тяжелым расстройствам таких систем, как желудочно-кишечной, сердечно-сосудистой и дыхательной. Комплексная диагностика этой патологии у собак разработана недостаточно. Высокая вариабельность клинических признаков при парвовирусном энтерите, сложность апелляичи большим числом качественных показателей затрудняют постановку диагноза на это заболевание для практического ветеринарного врача. Методы патоморфологической диагностики являются простыли, дешевыми и доступными практикующему врачу ветеринарной медицины. Именно с них начинается установления причины гибели животного, при многих болезнях и патологических состояниях эти методы остаются решающими при постановке диагноза.
\end{abstract}

\section{Citation:}

Radsikhovskii, N., Zaika, S. (2017). Pathomorphological characteristic of parvoverus external into dogs. Scientific Messenger LNUVMB, 19(82), 4549. 
Работу выполняли на факультете ветеринарной медицины Житомирского национального агроэкологического университета, а также в ветеринарных клиниках города Житомира: в период с 2014 по 2017 годы на породных и беспородных собаках.

Диагностические исследования в подтверждение парвовирусного энтерита проводили с помощью экспресс-тестов VetExpert и в ИФА и ПЦР.

В статье представлены результаты изучения патологоанатомических изменений у собак при парвовирусном энтерите, которые зависели от формы проявления болезни - кишечной, сердечной или смешанной. Наиболее выраженные патолого-анатомические изменения находили в желудочно-кишечном тракте (при кишечной форме), главным образом в тонком отделе кишечника. При кардиальной форме парвовирусного энтерита основные изменения наблюдали в сердие. Характерным для данной формы болезни является миокардит альтеративного типа.

У погибших животных выявлено комплекс патологоанатомических признаков, которые можно считать характерными для парвовирусного энтерита: геморрагический энтерит, серозно-геморрагическое воспаление брыжеечных лимфоузлов, признаки гепатита, острый альтеративный миокардит, в легких - кровоизлияния и очаги ателектазов и увеличение селезенки.

Ключевые слова: собаки, парвовирусный энтерит, патологоанатомическое вскрытие, макроскопические изменения, патоморфологическая диагностика, миокардит, кровоизлияния.

\title{
Pathomorphological characteristic of parvoverus external into dogs
}

\author{
N. Radsikhovskii, S. Zaika \\ nickvet@ukr.net, lana_zaika@ukr.net \\ Zhytomyr National Agroecological University, \\ Koroleva Str., 39, Zhytomyr, 10002, Ukraine
}

Viral enteritis occupy a leading place in the infectious pathology of dogs and lead to severe disorders of such systems as the gastrointestinal, cardiovascular and respiratory.

The comprehensive diagnosis of this pathology in dogs is not developed enough. The high variability of clinical signs for parvovirus enteritis, the complexity of the appeal with a large number of qualitative indicators, complicate the diagnosis of this disease for a practical veterinarian. The methods of pathomorphological diagnosis are simple, cheap and accessible to any veterinarian doctor. It is precisely from them that the causes of death of the animal begin to be established, with many diseases and pathological conditions, these methods remain decisive when making a diagnosis.

The aim of the work was to study and analyze the pathomorphological features in parvovirus enteritis of dogs.

Materials and methods of research. The work was carried out at the Faculty of Veterinary Medicine of the Zhytomyr National Agroecological University, as well as in the veterinary clinics of the city of Zhytomyr: the private veterinary clinics "Bagira» and "Doctor-Zoo", the educational and scientific-production clinic of veterinary medicine of the Faculty of Veterinary Medicine of the (ZNAEU) in the city state Zhitomir Hospital of Veterinary Medicine and Aybolit Private Veterinary Clinic in the period from 2014 to 2017 in breeding and breeding dogs.

Diagnostic studies to confirm parvovirus enteritis were performed using the VetExpert and ELISA and PCR rapid tests on the basis of the private veterinary laboratory of Bald Ltd. (Kyiv).

The pathoanatomical section of dogs of all ages who died from parvovirus enteritis was performed by partial evisceration in a generally accepted sequence.

The article presents the results of the study of pathoanatomical changes in dogs for parvovirus enteritis, which depended on the form of manifestation of the disease - intestinal, cardiac or mixed. The most pronounced pathological and anatomical changes were found in the gastrointestinal tract (intestinal form), mainly in the small intestine.

In the dead animals, a complex of pathoanatomical signs that can be considered characteristic of parvovirus enteritis are found: hemorrhagic enteritis, serous-hemorrhagic inflammation of the mesenteric lymph nodes, signs of hepatitis, acute altered myocarditis, and in the lungs - hemorrhages and foci of atelectasis and enlargement of the spleen.

Key words: dogs, parvovirus enteritis, pathologic anatomical autopsy, macroscopic changes, pathologic diagnostics myocarditis, hemorrhage.

\section{Вступ}

Вірусні захворювання домашніх тварин у міських умовах надзвичайно поширені, нерідко вони призводять до їх загибелі. У собак з усіх зареєстрованих вірусних захворювань найчастіше зустрічаються хвороби шлунково-кишкового тракту: вірусні ентерити (парво, корона та ротавірусний) - 43,1\%. Випадки ентеритів вірусної етіології зустрічаються надзвичайно часто але їх інтенсивність дещо варіює, а саме парво $(51,6 \%)$ - корона $(18,5 \%)$ та ротавірусний ентерит (23,5\%) (Park et al., 2012; Radzikhovs'kiy, 2016).

Сьогодні, не зважаючи на можливості своєчасної постановки діагнозу та різноманіття лікарських засо- бів, ще є багато хвороб, які призводять до загибелі тварин. Одною 3 них $є$ ентерити вірусної етіології. Собака може захворіти цією інфекцією при потраплянні вірусу в організм навіть при короткочасному контакті 3 інфікованою твариною або продуктами іiі життєдіяльності. Інфекція зазвичай вражає кишечник, викликаючи сильне запалення, зневоднення і часто закінчується летально. Парвовірусний ентерит може проявлятися в різних формах, тому від локалізації вірусу залежатиме перебіг хвороби і успіх лікувальних заходів.

Патоморфологічні зміни при парвовірусний інфекції собак вивчені досить поверхнево, особливо враховуючи полігамність патологічних змін. Сучасна 
ситуація щодо розповсюдження захворюваності на парвовірусний ентерит собак потребує інтенсифікації наукових досліджень у напрямі удосконалення діагностики останнього (Lund et al., 1999; Allison et al., 2014).

Патоморфологічний розтин $є$ всебічне вивчення загиблої або вбитої тварини з метою уточнення правильності прижиттєвого діагнозу, встановлення морфологічних змін в органах і причини смерті (Bil', 1950; Zharov et al., 2000).

Методи патоморфологічної діагностики є простими, дешевими та доступними будь-якому лікарю ветеринарної медицини. Саме $з$ них починається встановлення причини загибелі тварини, при багатьох хворобах і патологічних станах ці методи залишаються вирішальними при постановці діагнозу (Yesina and Potots'kyy, 2007).

Метою роботи було вивчити та проаналізувати патоморфологічні особливості при парвовірусному ентериті собак.

\section{Матеріал і методи досліджень}

Роботу виконували на факультеті ветеринарної медицини Житомирського національного агроекологічного університету (ЖНАЕУ), а також у ветеринарних клініках міста Житомира: приватних ветеринарних клініках «Багіра» і «Доктор-Zоо», навчальнонауково-виробничій клініці ветеринарної медицини факультету ветеринарної медицини ЖНАЕУ в міській державній лікарні ветеринарної медицини м. Житомира та приватній ветеринарній клініці «Айболит» в період з 2014 по 2017 роки на породних і безпородних собаках.

Діагностичні дослідження на підтвердження парвовірусного ентериту проводили за допомогою експрес-тестів VetExpert та в ІФА і ПЛР на базі приватної ветеринарної лабораторії ТОВ «Бальд» (м. Київ).

Патолого-анатомічний розтин собак різного віку, які загинули від парвовірусного ентериту, виконували методом часткової евісцерації в загальноприйнятій послідовності (Urbanovych et al., 2006).

\section{Результати та їх обговорення}

При патологоанатомічному розтині трупів загиблих тварин відмічали помірно виражене трупне задубіння. Трупи задовільної вгодованості. Шкіра без пошкоджень, зниженої еластичності, волосяний покрив тьмяний, висмикується легко. $Є$ скоринки підсихання серозного ексудату в ділянці крил носа. Навколо ротової порожнини засохлий слиз. Ділянка ануса i задні кінцівки забруднені кров'яними фекаліями.

Патолого-анатомічні зміни залежали від форми прояву хвороби - кишкової, серцевої або змішаної. Найбільш виражені патолого-анатомічні зміни знаходили у шлунково-кишковому тракті (при кишковій формі), головним чином у тонкому відділі кишечнику. Шлунок зазвичай був заповнений водянистими смердючими кормовими масами, вони в більшості випадків мали жовто-коричневий та червонокоричневий колір (рис. 1).

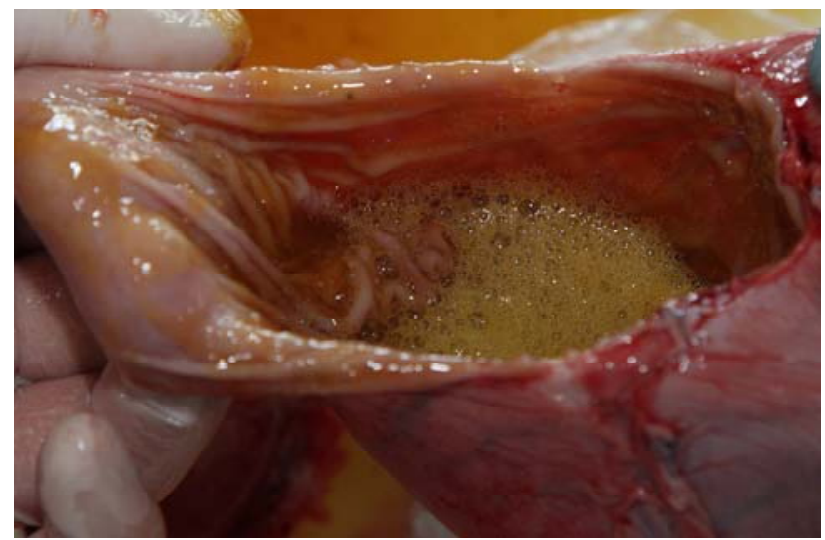

Рис.1. Вміст шлунка загиблої собаки при парвовірусному ентериті (кишкова форма хвороби)

Слизова оболонка шлунка в стані набряку, особливо на складках, нерівномірно забарвлена (рис. 2). Часто при кишковій формі хвороби слизова оболонка шлунку сірого та червоного кольору, з крововиливами, особливо на вершині складок.

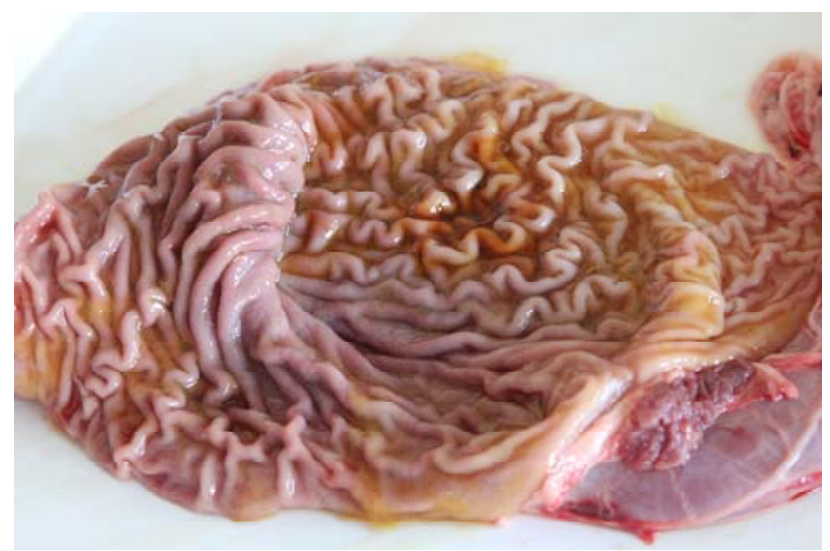

Рис. 2. Патолого-анатомічні зміни в шлунку собаки, загиблої від парвовірусного ентериту (кишкова форма хвороби)

При кишковій формі парвовірусного ентериту характерні зміни спостерігали в тонких кишках (рис. 3). Мезентеріальні лімфовузли набряклі, збільшені в розмірі. В тонкому відділі кишечнику і в його просвіті - рідкі кров'яні маси. Слизова оболонка цього відділу кишечнику, головним чином дванадцятипалої і порожньої кишок, набрякла, потовщена, драглистої консистенції, червоного або темно-червоного кольору, 3 численними крапково-плямистими крововиливами. Встановлено геморагічне запалення кишок (рис. 4).

У товстому відділі кишечнику зміни або відсутні, або слабко виражені. Вміст був чорно-червоного кольору 3 домішками крові. Слизова оболонка іноді набрякла, нерівномірно зафарбована, вкрита тягучим напіврідким вмістом. Мезентеріальні лімфатичні вузли збільшені, соковиті, почервонілі.

Селезінка у тварин загиблих за кишкової форми хвороби, збільшена, на її поверхні спостерігали ділянки зі світлими плямами та крайовими крововиливами (рис. 5). 


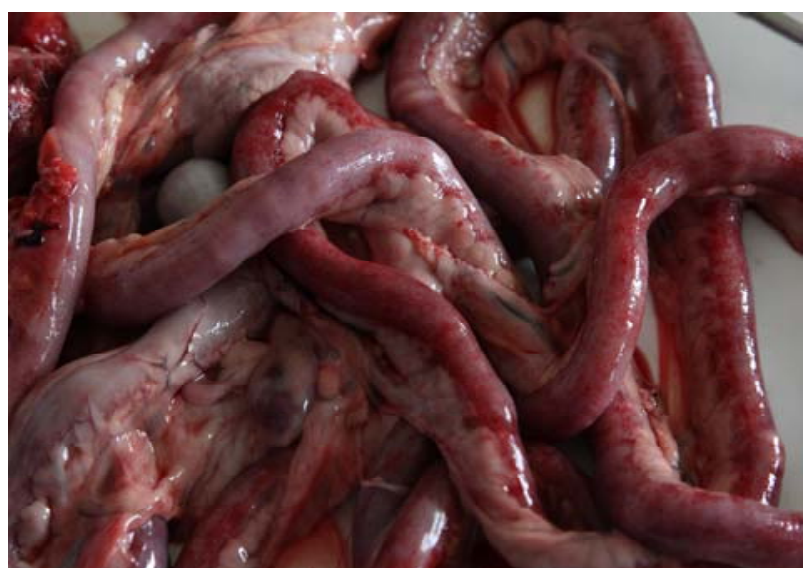

Рис. 3. Загальний вигляд кишечнику при парвовірусному ентериті собак

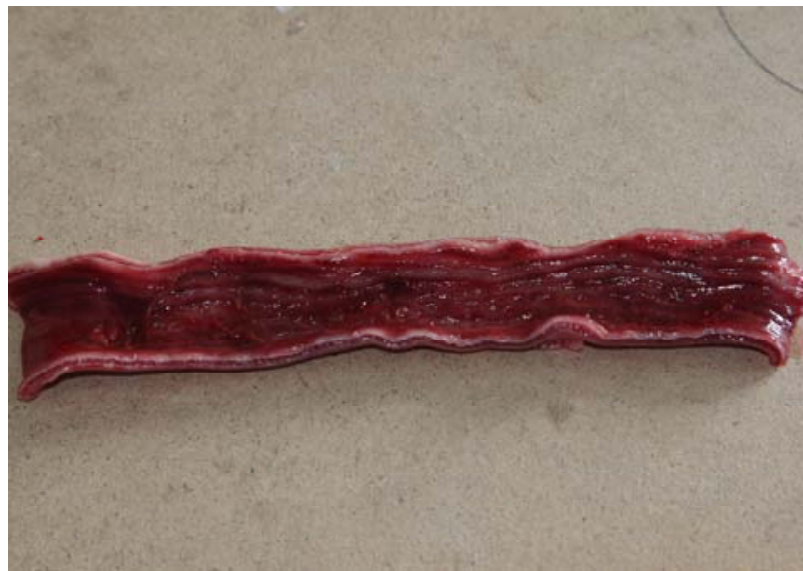

Рис. 4. Глибоке геморагічне запалення тонкого кишечнику в собаки за парвовірусного ентериту

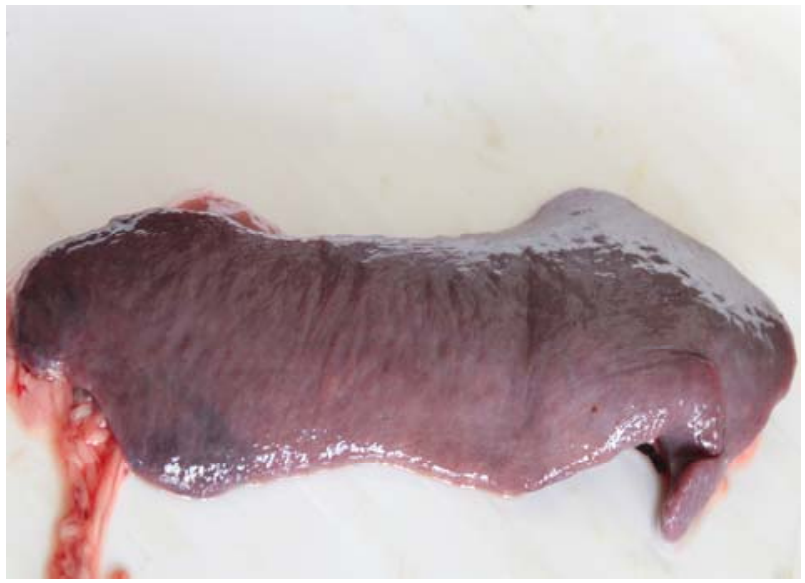

Рис. 5. Спленомегалія у собаки за парвовірусного ентериту (кишкова форма)

При зовнішньому огляді легень собак, загиблих 3 ознаками кишкової форми, парвовірусного ентериту, всі частки органу мали темно-червоний колір, консистенція тістувата, місцями пружна (рис. 6). На розрізі обидві легені мали строкатий малюнок, при дослідженні з бронхів виділялась кров'яниста рідина. За серцевої форми на поверхні органу спостерігали множинні крововиливи і вогнища ателектазів.

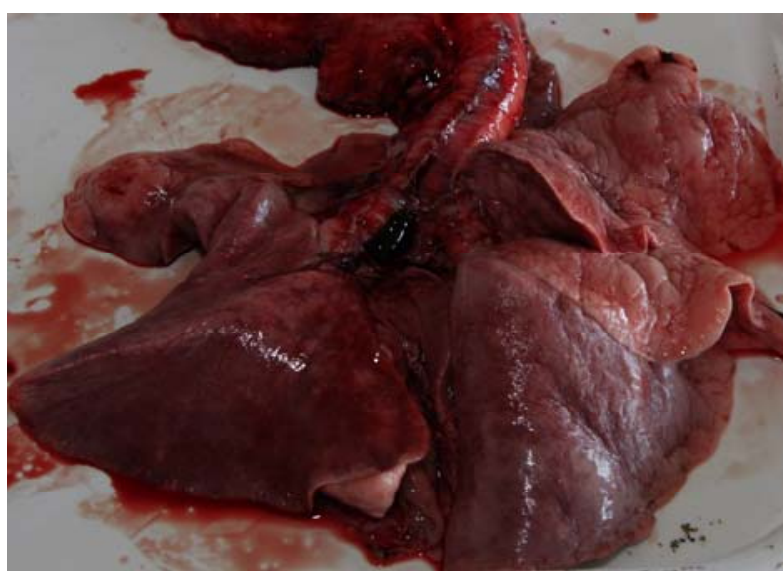

Рис. 6. Патолого-анатомічні зміни в легенях при кишковій формі парвовірусного ентериту собак

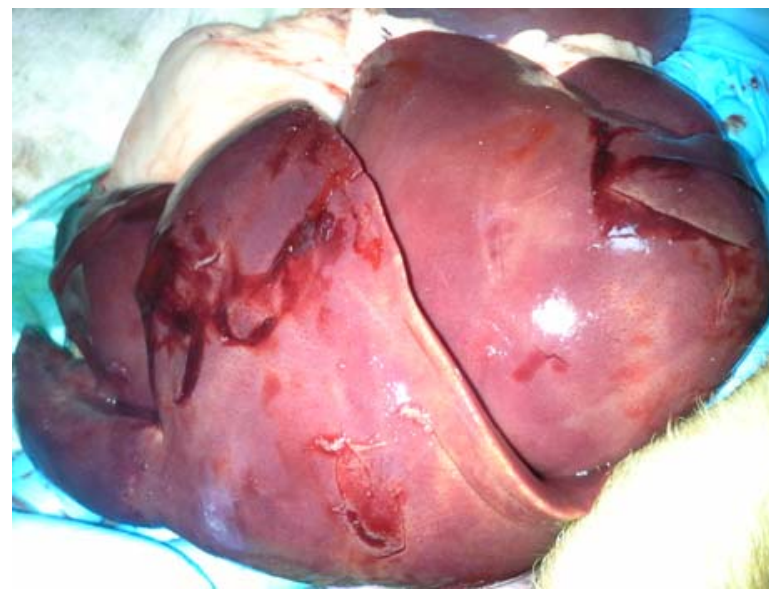

Рис. 7. Загальний вигляд печінки при парвовірусному ентериті собак

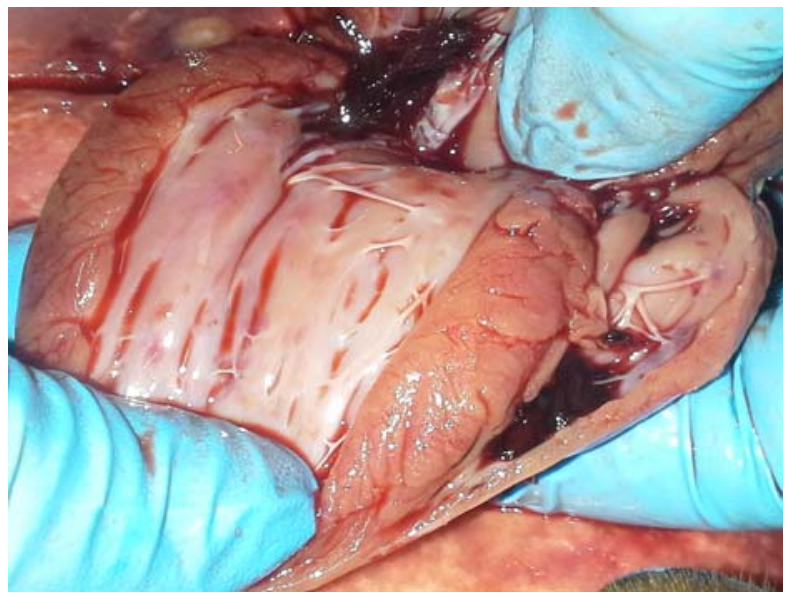

Рис. 8. Патолого-анатомічні зміни в серці собак за кардіальної форми парвовірусного ентериту

Також за кишкової форми парвовірусного ентериту відмічали характерні зміни в печінці. Вона була збільшена, пружної консистенції, бурого кольору, на поверхні розрізу виявлялися вогнища сірого кольору (рис. 7). У нирках анатомічних змін не виявлено.

При кардіальній формі парвовірусного ентериту основні зміни спостерігали в серці. Характерним для даної форми хвороби $є$ міокардит альтеративного типу: серце в ряді випадків було збільшене в об'ємі, округлої форми, колір сіро-білий, малюнок міокарда 
згладжений, відзначали дряблість його стінки (рис. 8). В інших органах іноді спостерігали набряк легень, ознаки гострого гепатиту й асциту, крововиливи.

У загиблих тварин виявлено комплекс патологоанатомічних ознак, які можна вважати характерними для парвовірусного ентериту: геморагічний ентерит, серозно-геморагічне запалення брижових лімфовузлів, ознаки гепатиту, гострий альтеративний міокардит, в легенях - крововиливи та вогнища ателектазів та збільшення селезінки.

\section{Висновки}

1. Виявлені патолого-анатомічні зміни у собак, загиблих від парвовірусного ентериту, відповідають двом формам хвороби - кардіальній та кишковій.

2. При кишковій формі парвовірусного ентериту основними патотолого-анатомічними змінами є: геморагічний ентерит, серозно-геморагічне запалення брижових лімфовузлів, ознаки гепатиту та збільшення селезінки.

3. Кардіальна форма хвороби характеризувалась гострим альтеративним міокардитом, в легенях крововиливами та вогнищами ателектазів.

Перспективи подальших досліджень. 3 метою повного охоплення патоморфологічної картини хвороби у подальшому доцільно провести гістологічні дослідження органів і тканин за парвовірусного ентериту собак.

\section{Бібліографічні посилання}

Radzikhovs'kiy, M.L. (2016). Monitorynh enteritiv virusnoyi etiolohiyi u sobak. Nauk. Visn. LNUVM ta
BT im. S.Z. Hzhyts'koho. 18, 1(65), 138-142 (in Ukrainian).

Park, S.A., Park, S.Y., Song, C.S. (2012). Development of a novel vaccine against canine parvovirus infection with a clinical isolate of the type $2 b$ strain. Clin Exp Vaccine Res. 1(1), 70-76.

Lund, E.M., Arm-strong, P.J., Kirk, C.A. (1999). Health status and population characteristics of dogs and cats examined at private veterinary prac-tices in the United States. Journal of the American Veterinary Medical Association. 214, 1336-1341.

Allison, A.B., Kohler, D.J., Ortega, A., Hoover, E.A., Grove, D.M., Holmes, E.P., Parrish, C.R. (2014). Host-specific parvovirus evolution in nature is recapitulated by in vitro adaptation to different carnivore species. PLoS. Pathog. 11, 6-10.

Zharov, A.V., Ivanov, I.V., Strel'nykov, A.P. (2000). Roztyn i patomorfolohycheskaya diahnostyka khvorob tvaryn. M.: Kolos (in Russian).

Bil', B.K. (1950). Patolohoanatomichnyy roztyn sil's'kohospodars'kykh tvaryn. M. (in Russian).

Yesina, E., Potots'kyy, M. (2007). Znachennya patomorfolohichnykh DOSLIDZHEN' u diahnostychnykh doslidzhennyakh tvaryn. Veterynarna medytsyna Ukrayiny. 3, 27-29.

Urbanovych, P.P., Potots'kyy, M.K., Hevkan, I.I. (2008). Patolohichna anatomiya tvaryn. K.: Vetinform (in Ukrainian).

Received 26.09.2017 Received in revised form 30.10.2017 Accepted 2.11.2017 